\section{Skriv norsk}

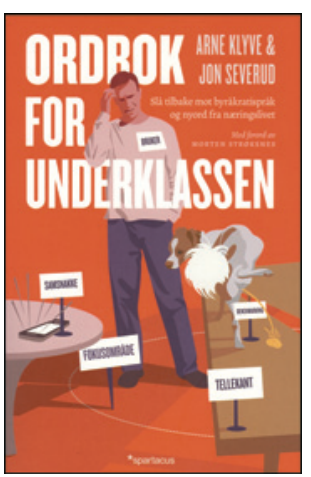

\section{God innføring i psykologisk førstehjelp}

Arne Klyve, Jon Severud

Ordbok for underklassen

Slå tilbake mot byråkratispråk og nyord fra næringslivet. 125 s, ill. Oslo: Spartacus, 2013. Pris NOK 299

ISBN 978-82-430-0707-9
Arne Klyve, undervisningssjef ved Bergensklinikkene, og Jon Severud, norsklektor, har med denne korte boken gitt oss en oversikt over det mylder av uforståelige nyord som har invadert oss de siste årene. På en måte er det merkelig at ingen har gjort dette før.

New Public Management er et begrep som har vært benyttet til å beskrive en rekke «reformer» innenfor det offentlige de siste 20-30 årene. Ifølge New Public Management vil en markedsorientering skape en mer dynamisk offentlig sektor og et billigere tilbud av offentlige tjenester uten negative bieffekter. Reformiveren har imidlertid ført til et voldsomt byråkrati, ikke minst innen helsevesenet og undervisningssektoren, og ofte intetsigende, språklig svada.

I alfabetisk orden omtaler forfatterne, til dels med humor, ord som er blitt gjengs i politikk og medier, fra agenda og analog læringsplattform til arbeidsplanfestet tid, arbeidstidsavtale, balansert målstyring, biomasse, coaching, dialogmøter, effektiviseringsgevinst, fokus, gjennomføringsgrad, helseforetak, implementering, kunnskapsløftet, lesestrategiskolering, målstyring, nærværsplaner, OPS, rammefinansiering, samhandlingsreform, tellekanter, utfasing, ventelistegaranti og så videre.

I gamle dager hadde båter, tog og buss passasjerer, leger hadde pasienter og skoler elever. Nå blir slike ord forsøkt erstattet av «kunder» eller «brukere». Medisinere har også latt seg blende av nyspråket. En del psykologer som misliker alt som smaker av medisin, har for eksempel brukt «klienter» om pasienter, og flere psykiatere har plapret etter. For øvrig hører vi at psykologer har vedtakskompetanse (postbud har sikkert frankeringskompetanse).

Kvalitetsreformen innen universitetene skulle vel bedre kvaliteten, men kvaliteten gikk ned fra hovedfag på seks år til master på fem og cand.mag. fra fire år til bachelor på tre. Det er tydeligvis ikke nok å være aktiv, man bør være proaktiv.

Ikke minst politikere har tatt i bruk New Public Managementspråket. Jan Tore Sanner interpellerer i Stortinget «om hvilken strategi regjeringen har for å stimulere til en bcerekraftig vekst som kan trygge velferden, med effektivisering og modernisering av offentlig sekton».

Grete Faremo, APs språklige tåkefyrste, er ikke i krig i Libya, men er med i en internasjonal væpnet konflikt, og de knapt 600 bombene vi slapp over Libya i 2011, var ikke krig, men et oppdrag.

Bjarne Håkon Hanssen gikk fra en ministerpost til verdiskapende arbeid i et konsulentfirma. «Til nå har jeg bare brukt penger, nå skal jeg over i det private næringsliv for å skape verdier.» For å skape verdier, eller som det ofte heter i dagens språk, levere varer, skal man helst fakturere kunder, flytte papirer på børsen eller arbeide i PR-bransjen.

Det er en nyttig bok forfatterne har skrevet.

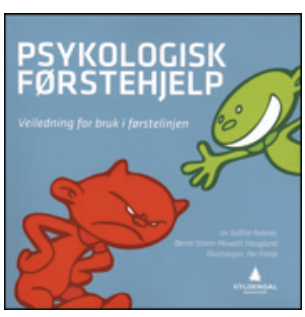

Solfrid Raknes, Bente Storm Mowatt Haugland Psykologisk førstehjelp

Veiledning for bruk i førstelinjen. 88 s, tab, ill. Oslo: Gyldendal Akademisk, 2013.

Pris NOK 165

ISBN 978-82-05-45108-7
Dette heftet er primært laget som en utvidet og mer generell veiledning for blant annet helsesøstre og foreldre ved bruk av det psykoedukative selvhjelpsmaterialet Psykologisk førstehjelp. Dette bygger på grunnelementer innen kognitiv atferdsterapi.

Plagsomme eller skremmende tanker konkretiseres og visualiseres ved tekst og en rød plastfigur, og hjelpsomme tanker ved hjelp av en grønn plastfigur. I tillegg er det en blokk med «hjelpehender» for utfylling av tanker. Målgruppen er barn og unge som trenger hjelp med symptomer som er plagsomme for barnet eller familien, for eksempel angst, depresjon, søvnvansker eller sosiale vansker.

Førsteforfatter utga dette materialet i 2010, og det blir nå i økende grad benyttet som et lavterskeltilbud i førstelinjetjenesten. Man har imidlertid etterlyst mer utfyllende informasjon beregnet for helsesøstre og foreldre. Det foreligger her.

Forfatterne er psykologspesialister, og i tillegg takker de en rekke erfarne fagfolk for støtte. Både tekst og referanser bekrefter en faglig bred tilnærming, bygd på det gjensidige forholdet mellom tanker, atferd, kroppsreaksjoner og følelser. «Ved å bevisstgjøre og hjelpe barn og unge til å endre for eksempel tanker eller adferd, vil også vanskelige følelser som sinne, skam eller angst kunne dempes eller håndteres.» Her er gode illustrasjoner av hjelpehender med fem fingre og kliniske eksempler: Hva skjer?, Følelser, Rødtanker, Grønntanker, Hva kan jeg gjøre? og Hvem kan hjelpe meg?.

Gode eksempler og realistiske beskrivelser av utfordringer, som motivasjon for endring, samarbeid med foreldre og tidsbruk, bidrar til at det er lett å gi dette heftet en meget positiv evaluering. Min eneste betenkning er tittelen på metoden. Psykologisk førstehjelp er i heftet definert som «selvhjelpsmateriell for barn i alderen 8-12 år og ungdom 13-18 år», men begrepet omfatter egentlig mye mer enn det som dekkes av denne modellen. En noe mer spesifikk betegnelse på materiale og metode ville vært hensiktsmessig.

Men dette er ikke til hinder for at jeg vil anbefale at både dette heftet og materialet blir godt kjent og brukt i førstelinjetjenesten. Det kan være nyttig for fastlegene å kjenne til psykologisk førstehjelp. Jeg håper også at helsesøstertjenesten bygges videre ut, både kvantitativt og kvalitativt, for å bidra til økt forståelse for og et bedre tilbud til barn og unge med psykiske symptomer og vansker.

Inger Helene Vandvik

Slependen 